\title{
Physiological role of adipose tissue: white adipose tissue as an endocrine and secretory organ
}

\author{
Paul Trayhurn ${ }^{1 *}$ and John H. Beattie ${ }^{2}$ \\ ${ }^{1}$ Institute for Nutrition Research, University of Oslo, PO Box 1046 Blindern, N-0316 Oslo, Norway \\ ${ }^{2}$ Rowett Research Institute, Bucksburn, Aberdeen AB21 9SB, UK
}

\begin{abstract}
The traditional role attributed to white adipose tissue is energy storage, fatty acids being released when fuel is required. The metabolic role of white fat is, however, complex. For example, the tissue is needed for normal glucose homeostasis and a role in inflammatory processes has been proposed. A radical change in perspective followed the discovery of leptin; this critical hormone in energy balance is produced principally by white fat, giving the tissue an endocrine function. Leptin is one of a number of proteins secreted from white adipocytes, which include angiotensinogen, adipsin, acylation-stimulating protein, adiponectin, retinol-binding protein, tumour neorosis factor $\alpha$, interleukin 6 , plasminogen activator inhibitor-1 and tissue factor. Some of these proteins are inflammatory cytokines, some play a role in lipid metabolism, while others are involved in vascular haemostasis or the complement system. The effects of specific proteins may be autocrine or paracrine, or the site of action may be distant from adipose tissue. The most recently described adipocyte secretory proteins are fasting-induced adipose factor, a fibrinogenangiopoietin-related protein, metallothionein and resistin. Resistin is an adipose tissue-specific factor which is reported to induce insulin resistance, linking diabetes to obesity. Metallothionein is a metal-binding and stress-response protein which may have an antioxidant role. The key challenges in establishing the secretory functions of white fat are to identify the complement of secreted proteins, to establish the role of each secreted protein, and to assess the pathophysiological consequences of changes in adipocyte protein production with alterations in adiposity (obesity, fasting, cachexia). There is already considerable evidence of links between increased production of some adipocyte factors and the metabolic and cardiovascular complications of obesity. In essence, white adipose tissue is a major secretory and endocrine organ involved in a range of functions beyond simple fat storage.
\end{abstract}

Cytokines: Fasting-induced adipose factor: Leptin: Metallothionein: Resistin

The growing concern with obesity has led to an emphasis on the 'undesirability' of white adipose tissue (WAT). Nevertheless, the tissue plays several key roles in mammalian physiology. The classical view of the function of WAT is that it provides a long-term fuel reserve which can be mobilised during food deprivation with the release of fatty acids for oxidation in other organs. Thus, the size of the adipose tissue stores increases in periods of positive energy balance and declines when energy expenditure is in excess of intake. WAT can also provide thermal insulation, and this is particularly evident in the case of the blubber of marine mammals such as seals and whales. Additional functions recently attributed to WAT include a mechanical role (blubber in whales), a role in inflammatory processes through preadi- pocytes acting as macrophage-like cells (Cousin et al. 1999) and a role in glucose homeostasis (Fig. 1). The last of these functions is elegantly demonstrated by transgenic mice containing little WAT; such lipodystrophic animals are diabetic, exhibiting both hyperglycaemia and substantial hyperinsulinaemia (Moitra et al. 1998; Shimomura et al. 1998).

The critical change in our perspectives on WAT came with the discovery of the cytokine-like factor, leptin (Zhang et al. 1994). An endocrine role for WAT in the regulation of energy balance and other physiological processes (see p. 332) has been established through the identification of leptin, the hormone being secreted principally from adipocytes, with actions both centrally (particularly in the

\footnotetext{
Abbreviations: FIAF, fasting-induced adipose factor; MT, metallothionein; TGF $\beta$, transforming growth factor $\beta$; TNF- $\alpha$, tumour necrosis factor $\alpha$; WAT, white adipose tissue.

*Corresponding author: Professor Paul Trayhurn, present address Department of Medicine, University of Liverpool, University Clinical Departments, Liverpool L69 3GA, UK, fax +44 151706 5802, email p_trayhurn@altavista.com
} 


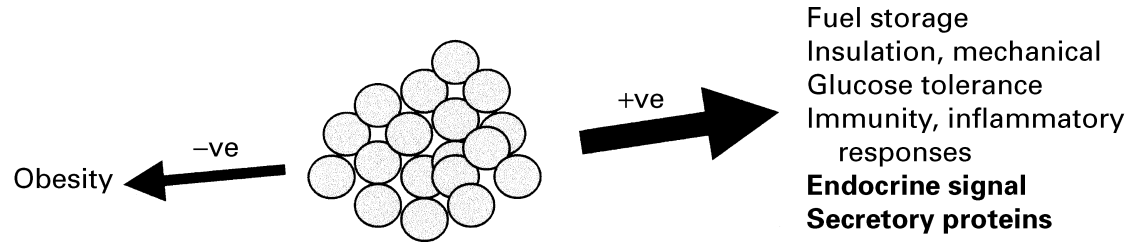

Fig. 1. Functions of white adipose tissue. A negative view of the tissue has been prevalent with the concern about obesity.

hypothalamus) and in peripheral organs (Fig. 1). Leptin is not, however, the only protein factor secreted by WAT. Indeed, there is a growing list of protein signals and factors that are released from white adipocytes (see Mohamed-Ali et al. 1998; Ahima \& Flier, 2000; Ailhaud, 2000; Trayhurn et al. 2001). The implication of these findings is clear, that white fat plays a wide-ranging role in metabolic regulation and physiological homeostasis, far beyond the simple paradigm of fat storage.

The present article considers the principal protein factors secreted from WAT, including the recently-documented secretory proteins, fasting-induced adipose factor (FIAF), metallothionein (MT) and resistin.

\section{Fatty acids and steroid secretions}

Before discussing protein factors, it is emphasised that quantitatively fatty acids are the major secretory product of WAT, reflecting the role of the tissue as a fuel reserve. White fat also stores cholesterol and is involved in the metabolism of steroid hormones. The tissue does not synthesise steroid hormones de novo but it does express enzymes which are involved in the conversion of both glucocorticoids and sex hormones, which are subsequently released (see Mohamed-Ali et al. 1998). Oestrone is converted to oestradiol and androstenedione to testosterone, while androgens can be aromatised to oestrogens.

The factors responsible for fatty acid release from WAT through the stimulation of lipolysis have been the subject of considerable scrutiny. It does, however, appear that physiologically the sympathetic nervous system is the key regulator of the breakdown of triacylglycerols (Hales et al. 1978). Recent studies involving direct measurements of tissue noradrenaline turnover have demonstrated that there is a marked sympathetic activation in white fat in specific situations in which there is net lipolysis, i.e. fasting and cold exposure (Garofalo et al. 1996; Migliorini et al. 1997). In fasted animals this sympathetic activation is highly selective to WAT, since noradrenaline turnover falls in other tissues such as brown fat and the heart (Landsberg \& Young, 1984).

\section{Methodological considerations}

There are several methodological considerations in exploring the endocrine and secretory role of adipose tissue. WAT is a heterogeneous organ, and this is the case both in terms of differences between individual depots and in the range of cells which are present within the tissue. Given the metabolic heterogeneity of the various WAT depots, it is important to establish the pattern of secretory proteins from each site and the relative importance of different sites in the synthesis of specific factors. The significance of heterogeneity is particularly evident in relation to an abdominal fat distribution, with the pathophysiological implications of such a distribution.

WAT does not consist only of adipocytes. Indeed, the tissue is composed of several cell types in addition to mature white adipocytes, with the stromal-vascular fraction which includes fibroblasts and macrophages accounting for at least half the total cell number (Hausman, 1985). The implication is that when adipose tissue is found to express a particular gene, it is important to determine whether the expression occurs within the mature adipocytes or in the other cell types that are present. The customary approach is to separate adipocytes from the stromal-vascular component by collagenase digestion and then to probe for the mRNA of interest in the two fractions. An alternative approach is to employ in situ hybridisation for the direct localisation of the mRNA within a cell type. Similarly, when a protein is identified in WAT, Western blotting on the proteins from the separate fractions or immunohistochemistry of the intact tissue can be used to establish whether it is localised to adipocytes.

Both in vivo and in vitro studies may be employed to investigate secretory proteins from WAT, although each clearly has its own specific objectives and limitations. In vivo approaches such as the collection of the venous drainage from WAT depots, or microdialysis, provide means by which the direct production of secreted proteins from the tissue can be determined. Collection of the venous drainage with the measurement of the arterio-venous difference in concentration of a protein (or other molecular species) has been fruitful in identifying net release in human studies (Frayn, 1999; see also Coppack, 2001). For in vitro studies, mature adipocytes may be harvested and incubated for short periods, with 'ceiling culture' providing a viable longer-term preparation (Zhang et al. 2000), and tissue explants have also been used. Alternatively, fibroblastic preadipocytes can be induced to differentiate into adipocytes in primary culture, or murine adipocyte clonal cell lines (e.g. 3T3-L1 or F442A) may be employed. Primary cell culture is the only option for long-term in vitro studies on human adipose tissue and the adipocytes of other frequently-used species such as pigs.

\section{Leptin: the adipocyte hormone}

Leptin (also termed OB protein) was discovered in 1994 by Friedman and colleagues (Zhang et al. 1994), with the identification of the mutant gene which underlies the development of the obesity of the $o b / o b$ mouse. The 
hormone, which is widely viewed as the most important protein factor secreted by WAT, has been extensively reviewed (see Friedman \& Halaas, 1998; Trayhurn et al. 1999; Ahima et al. 2000; Harris, 2000), and it is therefore our intention to summarise here only the central elements of its biology, primarily from the perspective of adipose tissue.

The leptin gene $(\operatorname{Lep}(o b))$ encodes a protein of molecular weight 18000 containing a signal sequence which is cleaved to produce the mature hormone of molecular weight 16000 (Zhang et al. 1994). Initial studies suggested that leptin was only synthesised in WAT, but it is now recognised that the hormone is produced in several additional sites. Synthesis occurs in brown adipose tissue, the stomach, placenta, mammary gland, ovarian follicles and certain fetal organs such as the heart and bone or cartilage, and perhaps even the brain (Trayhurn et al. 1999, 2001). Nevertheless, WAT is the principal site of production and the major determinant of the level of the circulating hormone. This fact is evident from the correlation between plasma leptin and indices of body fatness in both human subjects and experimental animals (Considine et al. 1996; Ostlund et al. 1996). It is also implicit in the observation that transgenic mice with little or no adipose tissue have very low circulating leptin levels (Moitra et al. 1998; Shimomura et al. 1998).

\section{Leptin production in adipose tissue}

The $o b$ gene is expressed in all WAT depots, but there are substantial differences in the levels of $o b$ mRNA between sites, as well as differences according to developmental stage and between species. In mature rodents the levels of $o b$ mRNA are highest in the gonadal and perirenal adipose tissue, and lowest in the subcutaneous depots (Trayhurn et al. 1995b). In human subjects, however, the subcutaneous tissue exhibits higher levels of $o b$ mRNA than omental fat (Hube et al. 1996; Montague et al. 1997). Rodent studies indicate that there are major developmental changes; in suckling rats, in contrast to adult animals, the level of $o b$ mRNA is much higher in the subcutaneous adipose tissue than in the internal fat (Rayner et al. 1997). Assuming that levels of mRNA reflect rates of leptin production, it would seem that in the suckling rodent subcutaneous adipose tissue is the main site of production of the hormone, but that after weaning the internal depots are more important.

There are a number of factors which acutely influence leptin synthesis in WAT, and these are superimposed on the endogenous level of production associated with the amount of body fat (see Trayhurn et al. 1999). Fasting leads to a rapid inhibition of $o b$ gene expression in WAT, and there is a concomitant fall in the level of circulating leptin; these effects are reversed on refeeding (Becker et al. 1995; Trayhurn et al. 1995b; Hardie et al. 1996). Acute exposure to cold also leads to a suppression of $o b$ gene expression and a decline in circulating leptin level (Trayhurn et al. 1995a; Hardie et al. 1996; Bing et al. 1998). Several hormones have been shown to affect leptin production by WAT. Insulin, glucocorticoids and cytokines such as tumour necrosis factor $\alpha(\mathrm{TNF}-\alpha)$ stimulate leptin production, as do oestrogens (see Trayhurn et al. 1999). In contrast, a major suppressive effect on leptin production occurs with catecho- lamines, both noradrenaline and adrenaline (Trayhurn et al. $1995 a$, 1999). The effect of catecholamines on leptin synthesis is mediated primarily through the $\beta 3$-adrenoceptor, the dominant $\beta$-receptor subtype in rodent adipose tissue (Giacobino, 1996), since selective $\beta 3$-agonists strongly suppress $o b$ gene expression and reduce circulating leptin levels (Gettys et al. 1996; Mantzoros et al. 1996; Trayhurn et al. 1996).

It is proposed that the sympathetic nervous system is the main physiological regulator of leptin production and that it provides a negative feedback loop to adipose tissue in the production of the hormone (Trayhurn et al. 1998). Evidence for this proposition comes in part from the effects of blocking noradrenaline production with $\alpha$-methyl- $p$ tyrosine, which leads to the rapid induction of hyperleptinaemia with increased levels of $o b$ mRNA in WAT (Rayner et al. 1998). Similarly, the administration of $\beta$-adrenoceptor antagonists, both the general antagonist propranolol and the selective $\beta 3$-antagonist SR 59230A, inhibits the fall in circulating leptin level occurring with cold exposure and on fasting (Evans et al. 1999; DV Rayner and P Trayhurn, unpublished results). This finding suggests that the reduction in leptin production with these stimuli is mediated primarily through sympathetic activation. The regulatory role of the sympathetic system is, however, complex (Sivitz et al. 1999).

The view that the sympathetic nervous system is an important regulator of leptin production in WAT reflects the current recognition that there is a significant sympathetic innervation of the tissue (Bartness \& Bamshad, 1998), there being direct nerve endings adjacent to adipocytes. Mapping studies with retrovirus techniques have indicated that part of the sympathetic innervation of WAT arises in hypothalamic areas associated with the regulation of energy balance (Bartness \& Bamshad, 1998). The sympathetic system is considered to be the main physiological mediator of lipolysis in WAT, as indicated earlier, and it also plays a trophic role in the tissue (Bartness \& Bamshad, 1998; Youngström \& Bartness, 1998).

The interaction between the sympathetic system and leptin is two-way, the hormone stimulating sympathetic activity in WAT and other tissues through its hypothalamic receptors (Haynes et al. 1997), while afferent signals from leptin sensors in white fat exert a reflex effect (Niijima, 1998). There is, therefore, communication from adipose tissue to the nervous system as well as in the opposite direction.

\section{Functions of leptin}

One or more isoforms of the leptin receptor are found in most tissues (Hoggard et al. 1997), including WAT, suggesting that the hormone may have an autocrine or paracrine function in adipose tissue. The leptin receptor long form (OB-Rb) splice variant, which is the key signalling form of the receptor (Lee et al. 1996), is found particularly in regions of the hypothalamus such as the arcuate nucleus and paraventricular nucleus (Mercer et al. 1996; Guan et al. 1997; Håkansson et al. 1998). Thus, parts of the brain associated with the central control of energy balance are a major target for leptin. 
Leptin interacts with several central neuroendocrine systems, including neuropeptide Y (Stephens et al. 1995; Ahima et al. 2000), leading to the inhibition of food intake (Campfield et al. 1995; Halaas et al. 1995; Pelleymounter et al. 1995). The functions attributed to the hormone, however, are extensive. Leptin affects energy expenditure, and acts as a major signal to the reproductive system (particularly in relation to sexual maturation in females) and as a factor in angiogenesis and in the immune system (Stehling et al. 1997; Bouloumie et al. 1998; Lord et al. 1998; SierraHonigmann et al. 1998). In addition to influencing these general physiological systems, leptin has been reported to affect a diverse spectrum of metabolic processes, ranging from the inhibition of insulin secretion by pancreatic $\beta$-cells to the stimulation of sugar transport and platelet aggregation (Emilsson et al. 1997; Lostao et al. 1998; Nakata et al. 1999).

In view of the many effects attributed to leptin the question has arisen as to whether there is a unifying function of the hormone, and two such ideas have been advanced. The first suggests that leptin is primarily a starvation signal (Ahima et al. 1996), the evidence for which includes the observation that several of the neuroendocrine and metabolic changes associated with fasting, as well as the immunosuppressive effects of starvation (Lord et al. 1998), can be reversed in the fasted animal by administering leptin. Another proposal suggests that a core role of leptin is to channel fatty acids into adipose tissue and limit triacylglycerol deposition in other tissues (Unger et al. 1999). This concept is based on the view that the function and viability of non-adipocytes can be compromised when the triacylglycerol content extends beyond the 'physiological' range.

\section{Other proteins secreted from adipose tissue}

A wide range of protein factors are secreted from WAT, in addition to leptin, and these are summarised in Fig. 2. They include other cytokines as well as proteins directly involved in lipid metabolism, in the complement system and in vascular haemostasis. The role of most of the diverse proteins secreted from WAT is not established, in terms of the physiological significance of production by adipose tissue. In principle, adipocyte factors could play either an autocrine or paracrine role within WAT, or have a broader endocrine function (or a combination thereof).

To date, because obesity has been a key focus of studies on adipose tissue, emphasis has been placed on the pathological significance of changes in the production of different secreted factors in the face of a greatly expanded adipose mass. However, it is also important to consider the implications on protein secretion of major reductions in the amount of WAT, for example as in chronic fasting, malnutrition and cancer cachexia. A key challenge is to provide a rationale in functional terms as to why particular factors are secreted from WAT, especially when they are but one element in a process involving a number of different proteins (as in vascular haemostasis).

\section{Proteins of lipid and lipoprotein metabolism}

Several proteins which play an important role in lipid and lipoprotein metabolism are released from white adipocytes. The enzyme lipoprotein lipase was in effect the earliest recognised protein secretory product of adipocytes. Lipoprotein lipase is responsible for the breakdown of circulating triacylglycerols, in the form of chylomicrons and VLDL, to fatty acids. A number of factors which regulate the expression of the lipoprotein lipase gene and the level and activity of the protein have been identified, with insulin playing an important role (Enerback \& Gimble, 1993). Other secreted proteins from WAT directly involved in lipid and lipoprotein metabolism include cholesteryl ester transfer protein and apolipoprotein E. Cholesteryl ester transfer protein plays an important role in the accumulation of cholesteryl ester by adipose tissue (see Mohamed-Ali et al. 1998; Radeau et al. 1998a,b). Indeed, WAT is a substantial site of the synthesis of cholesteryl ester transfer protein (Radeau et al. 1998a).

Retinol is stored in WAT, and the gene encoding the plasma retinol-binding protein is strongly expressed in adipocytes (Makover et al. 1989; Tsutsumi et al. 1992; Zovich et al. 1992). Retinol-binding protein mRNA is reported in practice to be one of the most abundant transcripts in rodent and human adipose tissue (Makover et al. 1989; Montague et al. 1998). Cell culture studies indicate that plasma retinol-binding protein is secreted from white

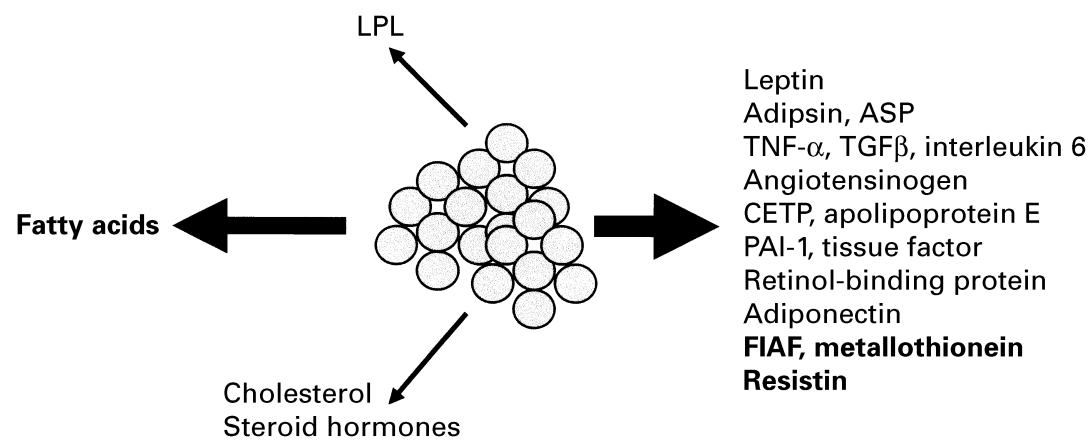

Fig. 2. Proteins factors secreted from white adipose tissue. ASP, acylation-stimulating protein; CETP, cholesteryl ester transfer protein; FIAF, fasting-induced adipose factor; LPL, lipoprotein lipase; PAI-1, plasminogen activator inhibitor-1; TGF $\beta$, transforming growth factor $\beta$; TNF- $\alpha$, tumour necrosis factor $\alpha$. 
adipocytes, and WAT presumably contributes to the total circulating pool (Tsutsumi et al. 1992; Zovich et al. 1992). Quantitatively, the liver and kidney have been regarded as the main sites of plasma retinol-binding protein production (Blomhoff et al. 1990), and the physiological significance of synthesis in adipose tissue is unclear.

\section{Angiotensinogen}

White adipocytes appear to be an important source of angiotensinogen, the substrate for renin in the renin-angiotensin system which plays a central role in blood pressure regulation. Indeed, WAT may be second only to the liver with respect to the production of angiotensinogen (Safonova et al. 1997). The activation product of angiotensinogen, angiotensin II, stimulates the production and release of prostacyclin which acts as a signal in the differentiation of preadipocytes to adipocytes (Zorad et al. 1995; Ailhaud et al. 2000). The circulating level of angiotensinogen is raised in obesity and this is thought to reflect the rise in adipose tissue mass. Thus, hypertension in the obese may result from the increased secretion of angiotensinogen (Engeli et al. 2000).

Adipose tissue expresses the genes encoding angiotensin converting enzyme and type 1 angiotensin receptor, in addition to angiotensinogen itself (Harp \& DiGirolamo, 1995; Karlsson et al. 1998; Engeli et al. 1999). This finding suggests that a local renin-angiotensin system is present in WAT (Ailhaud et al. 2000).

\section{Plasminogen activator inhibitor-1 and tissue factor}

At least two proteins involved in the fibrinolytic system and vascular haemostasis are secreted by WAT, i.e. tissue factor and plasminogen activator inhibitor-1. Tissue factor is the key cellular initiator of the coagulation cascade and acts as a cell-surface receptor for the activation of factor VII. Expression of the gene encoding tissue factor is higher in WAT of $o b / o b$ mice than in normal animals (Samad et al. 1998).

Plasminogen activator inhibitor-1, as its name implies, inhibits the activation of plasminogen, the precursor of plasmin which breaks down fibrin (see Booth, 2001). The plasminogen activator inhibitor-1 gene has been shown to be expressed and the encoded protein released in both human and rodent WAT (Lundgren et al. 1996; Eriksson et al. 1998; Cigolini et al. 1999). A number of factors stimulate plasminogen activator inhibitor-1 gene expression and the production of the protein by adipose tissue, including transforming growth factor $\beta$ (TGF $\beta$ ) and TNF- $\alpha$ which are themselves produced by adipose tissue (Samad et al. 1997; Sakamoto et al. 1999; Birgel et al. 2000).

The incidence of cardiovascular disease is increased in obesity, and this has been linked to the rise in the circulating level of plasminogen activator inhibitor-1 (Juhan-Vague \& Alessi, 1997); indeed, there is a correlation between plasminogen activator inhibitor-1 levels in plasma and BMI (Alessi et al. 1997). WAT appears to be a quantitatively significant site of plasminogen activator inhibitor-1 production, and the tissue may well be the source of the elevated levels in obesity (Lundgren et al. 1996; Samad et al. 1996; Samad \& Loskutoff, 1997; Alessi et al. 2000), although definitive evidence for this proposition is lacking.

\section{Cytokines and growth factors}

Several important 'classical' cytokines and growth factors are synthesised in WAT, particularly TNF- $\alpha$, interleukin 6 and TGF $\beta$ (see Mohamed-Ali et al. 1998; Coppack, 2001). TNF- $\alpha$ production is increased in obesity, and the cytokine has been implicated in the development of insulin resistance in the adipocyte of the obese by altering insulin signalling through an autocrine or paracrine action (Hotamisligil et al. 1993; Hotamisligil, 2000). The cytokine may also efflux from adipose tissue to contribute to the circulating level. The TGF $\beta$ gene is expressed in white fat and the level of both the mRNA and the protein are increased in geneticallyobese rodents (ob/ob and $d b / d b)$ compared with their lean counterparts (Samad et al. 1997). TGF $\beta$ is released from adipocytes and TNF- $\alpha$ stimulates expression of the gene and production of the protein (Samad et al. 1997). Interleukin 6 has recently been shown to be synthesised in WAT, both the mRNA and the protein being identified in the tissue, with increased levels of production in obesity (Mohamed-Ali et al. 1998, 1999; Bastard et al. 2000).

Given the multiplicity of effects now attributed to TNF- $\alpha$ and TGF $\beta$, including a role in the regulation of the synthesis of other adipose tissue-derived factors, these cytokines may play an important integrative function in WAT (Samad et al. 1999; Hotamisligil, 2000; Sethi \& Hotamisligil, 1999). Interaction is evident, with TNF- $\alpha$ stimulating the synthesis of TGF $\beta$, which in turn leads to an increase in the production of plasminogen-activator inhibitor-1, as noted earlier.

\section{Adipsin and acylation-stimulating protein}

Adipsin was the first major protein secreted from white fat to be identified (Cook et al. 1985), after lipoprotein lipase. It was discovered as a factor expressed in a differentiationdependent manner in adipocyte cell lines (Cook et al. 1985). An early observation was that expression of the adipsin gene is greatly decreased in animal models of obesity, with reduced levels of the circulating protein, leading to the initial view that it might be a lipostatic signal (Cook et al. 1987; Flier et al. 1987). However, adipsin, which is a serine protease and part of the alternative complement pathway (complement factor D), is not reduced in human obesity and is no longer regarded as a signalling molecule in energy balance.

Another protein of the alternative complement system is synthesised by WAT, i.e. acylation-stimulating protein, or C3ades-Arg, which is derived from the C3 complex through the action of adipsin, factor B and a carboxypeptidase. Several roles in lipid metabolism have been proposed for acylation-stimulating protein (Cianflone et al. 1999). Studies on transgenic mice lacking the protein through a deficiency of C3 support the hypothesis that acylationstimulating protein is important in the postprandial clearance of triacylglycerols (Murray et al. 1999a,b). The protein stimulates the uptake of fatty acids into white adipocytes and their esterification (Cianflone et al. 1999). 


\section{Adiponectin}

Adiponectin was originally identified from a cDNA, adipose most-abundant gene transcript 1 , reflecting a gene which is abundantly and specifically expressed in adipose tissue. The protein has homology with collagen VIII and collagen X, as well as with complement factor C1q (Maeda et al. 1997). It is suggested that adiponectin may modulate endothelial adhesion molecules and inhibit inflammatory responses, and there are also proposals that the protein is involved in the link between atherosclerosis and obesity (Ouchi et al. 1999; Yokota et al. 2000). In contrast to many proteins secreted by adipose tissue, expression of the adiponectin gene and the circulating level of the protein fall in obesity (Arita et al. 1999) and in diabetes (Hotta et al. 2000).

\section{Novel adipocyte-secreted proteins}

It is widely thought that there are likely to be a number of other proteins secreted from WAT additional to those identified to date. The discovery of new secreted proteins will come from the application of several experimental approaches, including microarrays to identify the range of genes expressed, specific differential expression studies, and proteomics to determine the protein complement of adipose tissue.

The three most recently described (late 2000 to early 2001) secretory proteins from WAT are FIAF, MT and resistin. The discovery of FIAF came from a subtractive hybridisation study (Kersten et al. 2000), while resistin was found in a screen for genes whose expression is induced during adipocyte differentiation but which are down regulated in mature fat cells in response to thiazolidinediones (Steppan et al. 2001a). In contrast, MT was identified following investigation of whether the MT gene is expressed in white fat, as it is in brown adipose tissue (Trayhurn et al. 2000a).

\section{Fasting-induced adipose factor}

The synthesis of FIAF, as implied by its name, is increased in response to fasting, and the factor itself belongs to the family of fibrinogen-angiopoietin-like proteins (Kersten et al. 2000). The gene encoding FIAF is predominantly expressed in WAT, although strong expression also occurs in brown fat. It is a target gene of the peroxisome proliferator-activated receptor $\alpha$ transcription factor; indeed,
FIAF was discovered in a study aimed at identifying unknown target genes for peroxisome proliferator-activated receptor $\alpha$. The protein is present in plasma, where the concentration is increased on fasting but decreased on feeding a high-fat diet (Kersten et al. 2000). It has been speculated that FIAF has an endocrine role and may be a signalling molecule which operates reciprocally to leptin.

\section{Resistin}

Resistin is a small, and potentially highly important, protein (molecular weight <10000) which is secreted from adipocytes, with the factor being present in serum (Steppan et al. 2001a). The initial report suggests that resistin is produced only by adipocytes, based on the tissue pattern of gene expression, with minimal expression in brown fat as compared with WAT. Expression of the resistin gene is reduced on fasting, with a parallel fall in the circulating level of the protein. In contrast, both gene expression and the plasma resistin level are increased in obese animals. Resistin induces insulin resistance; administration of the recombinant protein impairing glucose tolerance and insulin action (Steppan et al. 2001a). Correspondingly, treatment with antibodies to resistin improves glycaemia and reverses insulin resistance.

It is proposed that resistin is a key adipocyte signal in the induction of insulin resistance, and as such provides a molecular link between diabetes and obesity (Steppan et al. 2001a). The significance of this new factor could well prove to mirror that of leptin.

\section{Metallothionein}

MT, a low-molecular-weight (6000) stress-response and metal-binding protein, has long been recognised to be synthesised in several tissues, particularly the liver and kidney (Bremner \& Beattie, 1990). Among the tissues in which the MT gene is expressed is brown fat, where it is suggested that the protein may play an important antioxidant role (Beattie et al. 1996, 2000). In very recent studies we have demonstrated that both the MT- 1 and MT-2 genes are also expressed in WAT, the mRNA being present in each of the main depots, with no substantial site differences (Trayhurn et al. 2000a). The MT genes are expressed in the adipocytes themselves (Fig. 3) rather than in the cells of the stromal-vascular fraction (Trayhurn et al. 2000a).

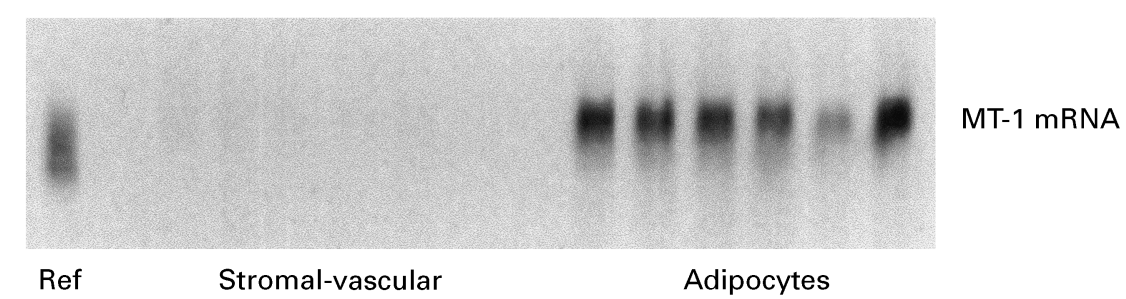

Fig. 3. Metallothionein (MT)-1 gene expression in white adipocytes. Mouse white adipose tissue was digested with collagenase and mature adipocytes separated from cells of the stromal-vascular fraction by centrifugation. Total RNA was extracted and Northern blots probed for MT-1 mRNA using a 28-mer antisense oligonucleotide (end labelled with digoxigenin) with chemiluminescence-based detection. Ref, reference white adipose tissue. 


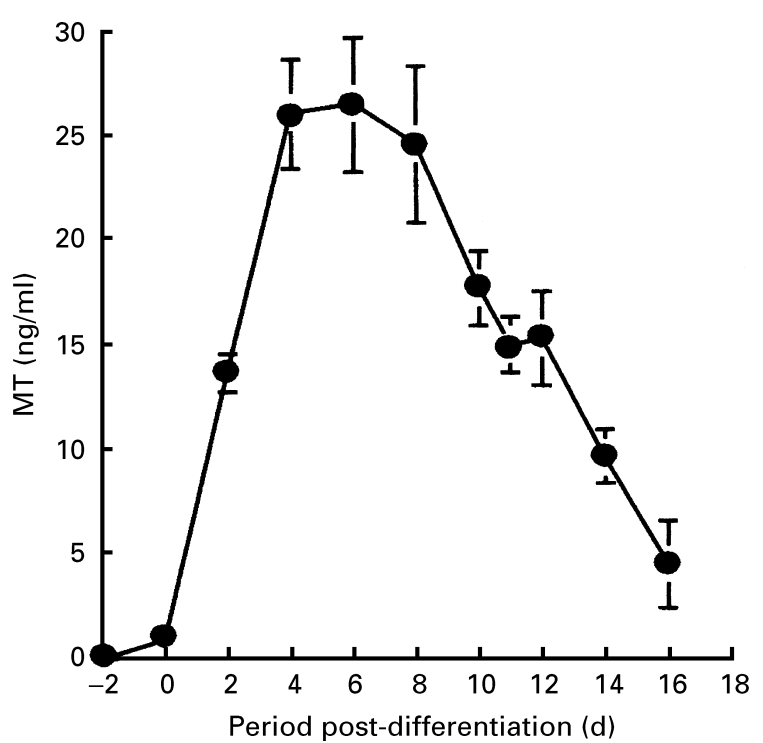

Fig. 4. Release of metallothionein (MT) into the medium on the differentiation of rat preadipocytes to adipocytes in primary culture. Fibroblastic preadipocytes from 2-week-old rats were induced to differentiate, the culture medium changed every $2 \mathrm{~d}$ and MT measured by radioimmunoassay. Values are means with their standard errors represented by vertical bars for six samples per group. (Adapted from Trayhurn et al. 2000a.)

In vivo studies have indicated that the level of MT-1 mRNA in WAT is unaltered by fasting, by the injection of noradrenaline, or even on administration of $\mathrm{Zn}$, which is a powerful inducer of MT production in the liver and kidney. However, injection of a $\beta 3$-agonist induced a modest increase in MT-1 mRNA level, suggesting that expression of the MT gene can be subject to adrenergic activation, given a sufficiently potent stimulus (Trayhurn et al. 2000a). In in vitro studies the differentiation of fibroblastic preadipocytes to adipocytes in primary culture resulted in a high level of MT mRNA and the release of MT protein into the medium (Fig. 4). This release occurred before the secretion of leptin and was not a reflection of the general leakage of cell contents (Trayhurn et al. 2000b). Both gene expression and the release of MT protein into the medium were stimulated by the glucocorticoid dexamethasone, and by forskolin and bromo-cAMP, agents which increase or mimic cAMP (Trayhurn et al. 2000b).

These observations indicate that MT is a previously unrecognised secretion product of white adipocytes, notwithstanding the lack of a signal sequence in the protein. A central question is the physiological role of MT both within adipocytes and as a secretory protein. We have suggested that the main function of MT in WAT may be as an antioxidant protecting fatty acids from oxidative damage (Trayhurn et al. 2000a), a proposition reflecting one of the general roles postulated for the protein (Miles et al. 2000). Certainly, there is a rapid induction of MT gene expression in brown adipocytes on acute exposure of rodents to the cold, consistent with a role for the protein in countering free radical damage during the high rates of $\mathrm{O}_{2}$ utilisation required for non-shivering thermogenesis (Beattie et al. 1996). In the case of white adipocytes, a housekeeping function is envisaged both within adipocytes and in adipose tissue during the transport of fatty acids. An alternative hypothesis for secreted MT is a signalling function, and there is some initial evidence for such a possibility (El Refaey et al. 1997).

\section{Coda}

There are several key challenges in the continuing investigation of the secretory functions of WAT: (1) to identify the full constellation of proteins secreted from adipocytes; (2) to determine the physiological role of each secreted protein; (3) to assess the pathophysiological consequences of changes in adipocyte protein production in response to major changes in adipose tissue mass; (4) to determine how the production of diverse proteins in different depots is coordinated. The pathophysiological implications of substantial changes in adipose tissue mass on the production and secretion of adipose tissue-derived factors are clearly important, and there is much evidence of links with the cardiovascular and metabolic complications of obesity. Although obesity has been the main focus to date, there is the possibility that changes in protein secretion associated with reductions in adipose tissue mass are also of significance. Thus, in conditions such as cancer cachexia, malnutrition and anorexia and during prolonged fasting there may be substantial alterations in the production of most of the proteins secreted from adipocytes (and this has been documented in some cases, such as leptin) with important metabolic and regulatory implications.

It is not easy to put forward a rational framework for why such a range of factors are secreted by white adipocytes, given the evident diversity of the proteins concerned. However, one hypothesis would be that the various factors may relate in some manner to the central lipid storage (and release) function of the tissue. It is now evident that WAT is a secretory and endocrine organ of considerable complexity which is highly integrated into the overall physiological and metabolic control systems of mammals, and much more so than the simple storage of fuel would imply. We now recognise there to be a distinct two-way communication between white adipocytes and the brain, through leptin and the sympathetic nervous system, with leptin stimulating sympathetic activity and the sympathetic system regulating the production of leptin (and other secretions). In essence, the white adipocyte can be seen to be a very 'smart' cell.

\section{Note added in proof}

A new report has indicated that there is a family of resistinlike molecules (REML), one of which, REML $\alpha$, is also expressed in WAT (Steppan et al. 2001b). This family is the same as the recently described FIZZ gene family of cysteine-rich secreted proteins (Holcomb et al. 2000), with FIZZ1 equating to REML $\alpha$ and FIZZ3 to resistin.

\section{Acknowledgements}

We acknowledge financial support from the Scottish Executive Rural Affairs Department. P.T. is grateful to the 
Throne Holst Foundation for an establishment grant at the University of Oslo.

\section{References}

Ahima RS \& Flier JS (2000) Adipose tissue as an endocrine organ. Trends in Endocrinology and Metabolism 11, 327-332.

Ahima RS, Prabakaran D, Mantzoros C, Qu DQ, Lowell B, Maratos-Flier E \& Flier JS (1996) Role of leptin in the neuroendocrine response to fasting. Nature 382, 250-252.

Ahima RS, Saper CB, Flier JS \& Elmquist JK (2000) Leptin regulation of neuroendocrine systems. Frontiers in Neuroendocrinology 21, 263-307.

Ailhaud G (2000) Adipose tissue as an endocrine organ. International Journal of Obesity 24, Suppl. 2, S1-S3.

Ailhaud G, Fukamizu A, Massiera F, Négrel R, Saint-Marc P \& Teboul M (2000) Angiotensinogen, angiotensin II and adipose tissue development. International Journal of Obesity 24, Suppl. 4, S33-S35.

Alessi MC, Bastelica D, Morange P, Berthet B, Leduc I, Verdier M, Geel O \& Juhan-Vague I (2000) Plasminogen activator inhibitor 1 , transforming growth factor-beta(1), and BMI are closely associated in human adipose tissue during morbid obesity. Diabetes 49, 1374-1380.

Alessi MC, Peiretti F, Morange P, Henry M, Nalbone G \& JuhanVague I (1997) Production of plasminogen activator inhibitor-1 by human adipose tissue - Possible link between visceral fat accumulation and vascular disease. Diabetes 46, 860-867.

Arita Y, Kihara S, Ouchi N, Takahashi M, Maeda K, Miyagawa J, Hotta K, Shimomura I, Nakamura T, Miyaoka K, Kuriyama H, Nishida M, Yamashita S, Okubo K, Matsubara K, Muraguchi M, Ohmoto Y, Funahashi T \& Matsuzawa Y (1999) Paradoxical decrease of an adipose-specific protein, adiponectin, in obesity. Biochemical and Biophysical Research Communications 257, 79-83.

Bartness TJ \& Bamshad M (1998) Innervation of mammalian white adipose tissue: implications for the regulation of total body fat. American Journal of Physiology 275, R1399-R1411.

Bastard JP, Jardel C, Bruckert E, Blondy P, Capeau J, Laville M, Vidal H \& Hainque B (2000) Elevated levels of interleukin 6 are reduced in serum and subcutaneous adipose tissue of obese women after weight loss. Journal of Clinical Endocrinology and Metabolism 85, 3338-3342.

Beattie JH, Black DJ, Wood AM \& Trayhurn P (1996) Coldinduced expression of the metallothionein-1 gene in brown adipose-tissue of rats. American Journal of Physiology 270, R971-R977.

Beattie JH, Wood AM, Trayhurn P, Jasani J, Vincent A, McCormack G \& West AK (2000) Metallothionein is expressed in adipocytes of brown fat and is induced by catecholamines and zinc. American Journal of Physiology 278, R1082-R1089.

Becker DJ, Ongemba LN, Brichard V, Henquin JC \& Brichard SM (1995) Diet-induced and diabetes-induced changes of $o b$ geneexpression in rat adipose-tissue. FEBS Letters 371, 324-328.

Bing C, Frankish HM, Pickavance L, Wang Q, Hopkins DFC, Stock MJ \& Williams G (1998) Hyperphagia cold-exposed rats is accompanied by decreased plasma leptin but unchanged hypothalamic NPY. American Journal of Physiology 274, R62-R68.

Birgel M, Gottschling-Zeller H, Rohrig K \& Hauner H (2000) Role of cytokines in the regulation of plasminogen activator inhibitor1 expression and secretion in newly differentiated subcutaneous human adipocytes. Arteriosclerosis Thrombosis and Vascular Biology 20, 1682-1687.

Blomhoff R, Green MH, Berg T \& Norum KR (1990) Transport and storage of vitamin A. Science 250, 399-404.
Bouloumie A, Drexler HCA, Lafontan M \& Busse R (1998) Leptin, the product of $\mathrm{Ob}$ gene, promotes angiogenesis. Circulation Research 83, 1059-1066.

Bremner I \& Beattie JH (1990) Metallothionein and the trace minerals. Annual Review of Nutrition 10, 63-83.

Campfield LA, Smith FJ, Guisez Y, De Vos R \& Burn P (1995) Recombinant mouse $O b$ protein - evidence for a peripheral signal linking adiposity and central neural networks. Science 269, 546-549.

Cianflone K, Maslowska M \& Sniderman AD (1999) Acylation stimulating protein (ASP), an adipocyte autocrine: new directions. Seminars in Cell and Developmental Biology 10, 31-41.

Cigolini M, Tonoli M, Borgato L, Frigotto L, Manzato F, Zeminian S, Cardinale C, Camin M, Chiaramonte E, DeSandre G \& Lunardi C (1999) Expression of plasminogen activator inhibitor1 in human adipose tissue: a role for TNF- $\alpha$ ? Atherosclerosis 143, 81-90.

Considine RV, Sinha MK, Heiman ML, Kriauciunas A, Stephens TW, Nyce MR, Ohannesian JP, Marco CC, McKee LJ, Bauer TL \& Caro JF (1996) Serum immunoreactive leptin concentrations in normal-weight and obese humans. New England Journal of Medicine 334, 292-295.

Cook KS, Groves DL, Min HY \& Spiegelman BM (1985) A developmentally regulated mRNA from $3 \mathrm{~T} 3$ adipocytes encodes a novel serine protease homologue. Proceedings of the National Academy of Sciences USA 82, 6480-6484.

Cook KS, Min HY, Johnson D, Chaplinsky RJ, Flier JS, Hunt CR \& Spiegelman BM (1987) Adipsin: a circulating serine protease homolog secreted by adipose tissue and sciatic nerve. Science 237, 402-405.

Coppack SW (2001) Pro-inflammatory cytokines and adipose tissue. Proceedings of the Nutrition Society 60, 349-356.

Cousin B, Munoz O, Andre M, Fontanilles AM, Dani C, Cousin JL, Laharrague P, Casteilla L \& Penicaud L (1999) A role for preadipocytes as macrophage-like cells. FASEB Journal 13, 305-312.

El Refaey H, Ebadi M, Kuszynski CA, Sweeney J, Hamada FM \& Hamed A (1997) Identification of metallothionein receptors in human astrocytes. Neuroscience Letters 231, 131-134.

Emilsson V, Liu YL, Cawthorne MA, Morton NM \& Davenport M (1997) Expression of the functional leptin receptor mRNA in pancreatic islets and direct inhibitory action of leptin on insulin secretion. Diabetes 46, 313-316.

Enerback S \& Gimble JM (1993) Lipoprotein lipase gene expression - physiological regulators at the transcriptional and post-transcriptional level. Biochimica et Biophysica Acta 1169, 107-125.

Engeli S, Gorzelniak K, Kreutz R, Runkel N, Distler A \& Sharma AM (1999) Co-expression of renin-angiotensin system genes in human adipose tissue. Journal of Hypertension 17, 555-560.

Engeli S, Negrel R \& Sharma AM (2000) Physiology and pathophysiology of the adipose tissue renin-angiotensin system. Hypertension 35, 1270-1277.

Eriksson P, Reynisdottir S, Lonnqvist F, Stemme V, Hamsten A \& Arner P (1998) Adipose tissue secretion of plasminogen activator inhibitor-1 in non-obese and obese individuals. Diabetologia 41, $65-71$.

Evans BA, Agar L \& Summers RJ (1999) The role of the sympathetic nervous system in the regulation of leptin synthesis in C57BL/6 mice. FEBS Letters 444, 149-154.

Flier JS, Cook KS, Usher P \& Spiegelman BM (1987) Severely impaired adipsin expression in genetic and acquired obesity. Science 237, 405-408.

Frayn KN (1999) Macronutrient metabolism of adipose tissue at rest and during exercise: a methodological viewpoint. Proceedings of the Nutrition Society 58, 877-885. 
Friedman JM \& Halaas JL (1998) Leptin and the regulation of body weight in mammals. Nature 395, 763-770.

Garofalo MAR, Kettelhut IC, Roselino JES \& Migliorini RH (1996) Effect of acute cold exposure on norepinephrine turnover rates in rat white adipose tissue. Journal of the Autonomic Nervous System 60, 206-208.

Gettys TW, Harkness PJ \& Watson PM (1996) The $\beta(3)$-adrenergic receptor inhibits insulin-stimulated leptin secretion from isolated rat adipocytes. Endocrinology 137, 4054-4057.

Giacobino JP (1996) Role of the $\beta$ (3)-adrenoceptor in the control of leptin expression. Hormone and Metabolic Research 28, 633-637.

Guan XM, Hess JF, Yu H, Hey PJ \& van der Ploeg LHT (1997) Differential expression of mRNA for leptin receptor isoforms in the rat brain. Molecular and Cellular Endocrinology 133, 1-7.

Håkansson ML, Brown H, Ghilardi N, Skoda RC \& Meister B (1998) Leptin receptor immunoreactivity in chemically defined target neurons of the hypothalamus. Journal of Neuroscience $\mathbf{1 8}$, 559-572.

Halaas JL, Gajiwala KS, Maffei M, Cohen SL, Chait BT, Rabinowitz D, Lallone RL, Burley SK \& Friedman JM (1995) Weight-reducing effects of the plasma-protein encoded by the obese gene. Science 269, 543-546.

Hales CN, Luzio JP \& Siddle K (1978) Hormonal control of adipose tissue lipolysis. Biochemical Society Transactions 43, 97-135.

Hardie LJ, Rayner DV, Holmes S \& Trayhurn P (1996) Circulating leptin levels are modulated by fasting, cold exposure and insulin administration in lean but not Zucker $(f a / f a)$ rats as measured by ELISA. Biochemical and Biophysical Research Communications 223, 660-665.

Harp JB \& DiGirolamo M (1995) Components of the reninangiotensin system in adipose-tissue - changes with maturation and adipose mass enlargement. Journals of Gerontology 50, B270-B276.

Harris RB (2000) Leptin - much more than a satiety signal. Annual Review of Nutrition 20, 45-75.

Hausman GJ (1985) The comparative anatomy of adipose tissue. In New Perspectives in Adipose Tissue: Structure, Function and Development, pp. 1-21 [A Cryer and RL Van, editors]. London: Butterworths.

Haynes WG, Morgan DA, Walsh SA, Mark AL \& Sivitz WI (1997) Receptor-mediated regional sympathetic nerve activation by leptin. Journal of Clinical Investigation 100, 270-278.

Hoggard N, Mercer JG, Rayner DV, Moar K, Trayhurn P \& Williams LM (1997) Localization of leptin receptor mRNA splice variants in murine peripheral tissues by RT-PCR and in situ hybridization. Biochemical and Biophysical Research Communications 232, 383-387.

Holcomb IN, Kabakoff RC, Chan B, Baker TW, Gurney A, Henzel W, Nelson C, Lowman HB, Wright BD, Skelton NJ, Frantz GD, Tumas DB, Peale F, Shelton DL \& Hebert CC (2000) FIZZ1, a novel cysteine-rich secreted protein associated with pulmonary inflammation, defines a new gene family. EMBO Journal 19, 4046-4055.

Hotamisligil GS (2000) Molecular mechanisms of insulin resistance and the role of the adipocyte. International Journal of Obesity 24, S23-S27.

Hotamisligil GS, Shargill NS \& Spiegelman BM (1993) Adipose expression of tumor necrosis factor- $\alpha$ - direct role in obesitylinked insulin resistance. Science 259, 87-91.

Hotta K, Funahashi T, Arita Y, Takahashi M, Matsuda M, Okamoto Y, Iwahashi H, Kuriyama H, Ouchi N, Maeda K, Nishida M, Kihara S, Sakai N, Nakajima T, Hasegawa K, Muraguchi M, Ohmoto Y, Nakamura T, Yamashita S, Hanafusa $T$ \& Matsuzawa Y (2000) Plasma concentrations of a novel, adipose-specific protein, adiponectin, in type 2 diabetic patients.
Arteriosclerosis Thrombosis and Vascular Biology 20 1595-1599.

Hube F, Lietz U, Igel M, Jensen PB, Tornqvist H, Joost HG \& Hauner H (1996) Difference in leptin mRNA levels between omental and subcutaneous abdominal adipose tissue from obese humans. Hormone and Metabolic Research 28, 690-693.

Juhan-Vague I \& Alessi MC (1997) PAI-1, obesity, insulin resistance and risk of cardiovascular events. Thrombosis and Haemostasis 78, 656-660.

Karlsson C, Lindell K, Ottosson M, Sjostrom L, Carlsson B \& Carlsson LMS (1998) Human adipose tissue expresses angiotensinogen and enzymes required for its conversion to angiotensin II. Journal of Clinical Endocrinology and Metabolism 83, 3925-3929.

Kersten S, Mandard S, Tan NS, Escher P, Metzger D, Chambon P, Gonzalez FJ, Desvergne B \& Wahli W (2000) Characterization of the fasting-induced adipose factor FIAF, a novel peroxisome proliferator-activated receptor target gene. Journal of Biological Chemistry 275, 28488-28493.

Landsberg L \& Young JB (1984) The role of the sympathoadrenal system in modulating energy expenditure. Clinics in Endocrinology and Metabolism 13, 475-499.

Lee GH, Proenca R, Montez JM, Carroll KM, Darvishzadeh JG, Lee JI \& Friedman JM (1996) Abnormal splicing of the leptin receptor in diabetic mice. Nature 379, 632-635.

Lord GM, Matarese G, Howard LK, Baker RJ, Bloom SR \& Lechler RI (1998) Leptin modulates the T-cell immune response and reverses starvation-induced immunosuppression. Nature 394, 897-901.

Lostao MP, Urdaneta E, Martinez-Anso E, Barber A \& Martinez JA (1998) Presence of leptin receptors in rat small intestine and leptin effect on sugar absorption. FEBS Letters 423, 302-306.

Lundgren CH, Brown SL, Nordt TK, Sobel BE \& Fujii S (1996) Elaboration of type-1 plasminogen activator inhibitor from adipocytes - A potential pathogenetic link between obesity and cardiovascular disease. Circulation 93, 106-110.

Maeda K, Okubo K, Shimomura I, Mizuno K, Matsuzawa Y \& Matsubara K (1997) Analysis of an expression profile of genes in the human adipose tissue. Gene 190, 227-235.

Makover A, Soprano DR, Wyatt ML \& Goodman DS (1989) Localization of retinol-binding protein mRNA in the rat kidney and in perinephric fat tissue. Journal of Lipid Research 30, $171-180$.

Mantzoros CS, Qu DQ, Frederich RC, Susulic VS, Lowell BB, Maratos-Flier E \& Flier JS (1996) Activation of $\beta 3$ adrenergic receptors suppresses leptin expression and mediates a leptinindependent inhibition of food intake in mice. Diabetes 45, 909-914.

Mercer JG, Hoggard N, Williams LM, Lawrence CB, Hannah LT \& Trayhurn P (1996) Localization of leptin receptor mRNA and the long form splice variant $(\mathrm{Ob}-\mathrm{Rb})$ in mouse hypothalamus and adjacent brain regions by in situ hybridization. FEBS Letters $\mathbf{3 8 7}$, 113-116.

Migliorini RH, Garofalo MAR \& Kettelhut IC (1997) Increased sympathetic activity in rat white adipose tissue during prolonged fasting. American Journal of Physiology 272, R656-R661.

Miles AT, Hawksworth GM, Beattie JH \& Rodilla V (2000) Induction, regulation, degradation and biological significance of mammalian metallothioneins. Critical Reviews in Biochemistry and Molecular Biology 35, 35-70.

Mohamed-Ali V, Goodrick S, Bulmer K, Holly JMP, Yudkin JS \& Coppack SW (1999) Production of soluble tumor necrosis factor receptors by human subcutaneous adipose tissue in vivo. American Journal of Physiology 277, E971-E975.

Mohamed-Ali V, Pinkney JH \& Coppack SW (1998) Adipose tissue as an endocrine and paracrine organ. International Journal of Obesity 22, 1145-1158. 
Moitra J, Mason MM, Olive M, Krylov D, Gavrilova O, MarcusSamuels B, Feigenbaum L, Lee E, Aoyama T, Eckhaus M, Reitman ML \& Vinson C (1998) Life without white fat: a transgenic mouse. Genes and Development 12, 3168-3181.

Montague CT, Prins JB, Sanders L, Digby JE \& O'Rahilly S (1997) Depot- and sex-specific differences in human leptin mRNA expression: Implications for the control of regional fat distribution. Diabetes 46, 342-347.

Montague CT, Prins JB, Sanders L, Zhang JL, Sewter CP, Digby J, Byrne CD \& O'Rahilly S (1998) Depot-related gene expression in human subcutaneous and omental adipocytes. Diabetes 47, 1384-1391.

Murray I, Sniderman AD \& Cianflone K (1999a) Mice lacking acylation stimulating protein (ASP) have delayed postprandial triglyceride clearance. Journal of Lipid Research 40, 1671-1676.

Murray I, Sniderman AD, Havel PJ \& Cianflone K (1999b) Acylation stimulating protein (ASP) deficiency alters postprandial and adipose tissue metabolism in male mice. Journal of Biological Chemistry 274, 36219-36225.

Mutch NJ, Wilson HM, Booth NA (2001) Plasminogen activator inhibitor-1 and haemostasis in obesity. Proceedings of the Nutrition Society 60, 341-341.

Nakata M, Yada T, Soejima N \& Maruyama I (1999) Leptin promotes aggregation of human platelets via the long form of its receptor. Diabetes 48, 426-429.

Niijima A (1998) Afferent signals from leptin sensors in the white adipose tissue of the epididymis, and their reflex effect in the rat. Journal of the Autonomic Nervous System 73, 19-25.

Ostlund RE, Yang JW, Klein S \& Gingerich R (1996) Relation between plasma leptin concentration and body fat, gender, diet, age, and metabolic covariates. Journal of Clinical Endocrinology and Metabolism 81, 3903-3913.

Ouchi N, Kihara S, Arita Y, Maeda K, Kuriyama H, Okamoto Y, Hotta K, Nishida M, Takahashi M, Nakamura T, Yamashita S, Funahashi T \& Matsuzawa Y (1999) Novel modulator for endothelial adhesion molecules - Adipocyte-derived plasma protein adiponectin. Circulation 100, 2473-2476.

Pelleymounter MA, Cullen MJ, Baker MB, Hecht R, Winters D, Boone T \& Collins F (1995) Effects of the obese gene-product on body-weight regulation in ob/ob mice. Science 269, 540-543.

Radeau T, Robb M, Lau P, Borthwick J \& McPherson R (1998a) Relationship of adipose tissue cholesteryl ester transfer protein (CETP) mRNA to plasma concentrations of CETP in man. Atherosclerosis 139, 369-376.

Radeau T, Robb M, McDonnell M \& McPherson R (1998b) Preferential expression of cholesteryl ester transfer protein mRNA by stromal-vascular cells of human adipose tissue. Biochimica et Biophysica Acta 1392, 245-253.

Rayner DV, Dalgliesh GD, Duncan JS, Hardie LJ, Hoggard N \& Trayhurn P (1997) Postnatal development of the $o b$ gene system: Elevated leptin levels in suckling fa/fa rats. American Journal of Physiology 273, R446-R450.

Rayner DV, Simon E, Duncan JS \& Trayhurn P (1998) Hyperleptinaemia in mice induced by administration of the tyrosine hydroxylase inhibitor $\alpha$-methyl-p-tyrosine. FEBS Letters $\mathbf{4 2 9}$, 395-398.

Safonova I, Aubert J, Négrel R \& Ailhaud G (1997) Regulation by fatty acids of angiotensinogen gene expression in preadipose cells. Biochemical Journal 322, 235-239.

Sakamoto T, Woodcock-Mitchell J, Marutsuka K, Mitchell JJ, Sobel BE \& Fujii S (1999) TNF- $\alpha$ and insulin, alone and synergistically, induce plasminogen activator inhibitor-1 expression in adipocytes. American Journal of Physiology 276, C1391-C1397.

Samad F \& Loskutoff DJ (1997) The fat mouse: A powerful genetic model to study elevated plasminogen activator inhibitor 1 in Obesity/NIDDM. Thrombosis and Haemostasis 78, 652-655.
Samad F, Pandey M \& Loskutoff DJ (1998) Tissue factor gene expression in the adipose tissues of obese mice. Proceedings of the National Academy of Sciences USA 95, 7591-7596.

Samad F, Uysal KT, Wiesbrock SM, Pandey M, Hotamisligil GS \& Loskutoff DJ (1999) Tumor necrosis factor $\alpha$ is a key component in the obesity-linked elevation of plasminogen activator inhibitor 1. Proceedings of the National Academy of Sciences USA 96, 6902-6907.

Samad F, Yamamoto K \& Loskutoff DJ (1996) Distribution and regulation of plasminogen activator inhibitor-1 in murine adipose tissue in vivo - Induction by tumor necrosis factor- $\alpha$ and lipopolysaccharide. Journal of Clinical Investigation 97, $37-46$.

Samad F, Yamamoto K, Pandey M \& Loskutoff DJ (1997) Elevated expression of transforming growth factor- $\beta$ in adipose tissue from obese mice. Molecular Medicine 3, 37-48.

Sethi JK \& Hotamisligil GS (1999) The role of TNF $\alpha$ in adipocyte metabolism. Seminars in Cell and Developmental Biology 10, 19-29.

Shimomura I, Hammer RE, Richardson JA, Ikemoto S, Bashmakov Y, Goldstein JL \& Brown MS (1998) Insulin resistance and diabetes mellitus in transgenic mice expressing nuclear SREBP1c in adipose tissue: model for congenital generalized lipodystrophy. Genes and Development 12, 3182-3194.

Sierra-Honigmann MR, Nath AK, Murakami C, Garcia-Cardena G, Papapetropoulos A, Sessa WC, Madge LA, Schechner JS, Schwabb MB, Polverini PJ \& Flores-Riveros JR (1998) Biological action of leptin as an angiogenic factor. Science 281, 1683-1686.

Sivitz WI, Fink BD, Morgan DA, Fox JM, Donohoue PA \& Haynes WG (1999) Sympathetic inhibition, leptin, and uncoupling protein subtype expression in normal fasting rats. American Journal of Physiology 277, E668-E677.

Stehling O, Döring H, Nusslein-Hildesheim B, Olbort M \& Schmidt I (1997) Leptin does not reduce body fat content but augments cold defense abilities in thermoneutrally reared rat pups. Pflügers Archiv - European Journal of Physiology 434, 694-697.

Stephens TW, Basinski M, Bristow PK, Buevalleskey JM, Burgett SG, Craft L, Hale J, Hoffmann J, Hsiung HM, Kriauciunas A, Mackellar W, Rosteck PR, Schoner B, Smith D, Tinsley FC, Zhang XY \& Heiman M (1995) The role of neuropeptide-Y in the antiobesity action of the obese gene-product. Nature $\mathbf{3 7 7}$, $530-532$.

Steppan CM, Bailey ST, Bhat S, Brown EJ, Banerjee RR, Wright CM, Patel HR, Ahima RS \& Lazar MA (2001a) The hormone resistin links obesity to diabetes. Nature 409, 307-312.

Steppan CM, Brown EJ, Wright CM, Bhat S, Banerjee RR, Dai CY, Enders GH, Silberg DG, Wen X, Wu GD \& Lazar MA (2001b) A family of tissue-specific resistin-like molecules. Proceedings of the National Academy of Sciences USA 98, 502-506.

Trayhurn P, Duncan JS, Hoggard N \& Rayner DV (1998) Regulation of leptin production: a dominant role for the sympathetic nervous system? Proceedings of the Nutrition Society 57, 413-419.

Trayhurn P, Duncan JS \& Rayner DV (1995a) Acute cold-induced suppression of $o b$ (obese) gene-expression in white adiposetissue of mice - mediation by the sympathetic system. Biochemical Journal 311, 729-733.

Trayhurn P, Duncan JS, Rayner DV \& Hardie LJ (1996) Rapid inhibition of $o b$ gene expression and circulating leptin levels in lean mice by the $\beta 3$-adrenoceptor agonists BRL 35135A and ZD2079. Biochemical and Biophysical Research Communications 228, 605-610.

Trayhurn P, Duncan JS, Wood AM \& Beattie JH (2000a) Metallothionein gene expression and secretion by white adipose tissue. American Journal of Physiology 279, R2329-R2335. 
Trayhurn P, Duncan JS, Wood AM \& Beattie JH (2000b) Regulation of metallothionein gene expression and secretion in rat adipocytes differentiated from preadipocytes in primary culture. Hormone and Metabolic Research 32, 542-547.

Trayhurn P, Hoggard N, Mercer JG \& Rayner DV (1999) Leptin: fundamental aspects. International Journal of Obesity 23, 22-28.

Trayhurn P, Hoggard N \& Rayner DV (2001) White adipose tissue as a secretory and endocrine organ: Leptin and other secreted proteins. In Adipose Tissue [S Klaus, editor]. Austin, TX: Landes Bioscience (In the Press).

Trayhurn P, Thomas MEA, Duncan JS \& Rayner DV (1995b) Effects of fasting and refeeding on $o b$ gene-expression in white adipose-tissue of lean and obese $(o b / o b)$ mice. FEBS Letters 368 , 488-490.

Tsutsumi C, Okuno M, Tannous L, Piantedosi R, Allan M, Goodman DS \& Blaner WS (1992) Retinoids and retinoidbinding protein expression in rat adipocytes. Journal of Biological Chemistry 267, 1805-1810.

Unger RH, Zhou YT \& Orci L (1999) Regulation of fatty acid homeostasis in cells: Novel role of leptin. Proceedings of the National Academy of Sciences USA 96, 2327-2332.

Yokota T, Oritani K, Takahashi I, Ishikawa J, Matsuyama A, Ouchi N, Kihara S, Funahashi T, Tenner AJ, Tomiyama Y \&
Matsuzawa Y (2000) Adiponectin, a new member of the family of soluble defense collagens, negatively regulates the growth of myelomonocytic progenitors and the functions of macrophages. Blood 96, 1723-1732.

Youngström TG \& Bartness TJ (1998) White adipose tissue sympathetic nervous system denervation increases fat pad mass and fat cell number. American Journal of Physiology $\mathbf{2 7 5}$, R1488-R1493.

Zhang HH, Kumar S, Barnett AH \& Eggo MC (2000) Ceiling culture of mature human adipocytes: use in studies of adipocyte functions. Journal of Endocrinology 164, 119-128.

Zhang YY, Proenca R, Maffei M, Barone M, Leopold L \& Friedman JM (1994) Positional cloning of the mouse obese gene and its human homolog. Nature 372, 425-432.

Zorad S, Fickova M, Zelezna B, Macho L \& Kral JG (1995) The role of angiotensin II and its receptors in regulation of adipose tissue metabolism and cellularity. General Physiology and Biophysics 14, 383-391.

Zovich DC, Orologa A, Okuno M, Kong LW, Talmage DA, Piantedosi R, Goodman DS \& Blaner WS (1992) Differentiationdependent expression of retinoid-binding proteins in BFC-1 beta adipocytes. Journal of Biological Chemistry 267, 13884-138890. 